Journal of Student Wellbeing

October 2008, Vol. 2(1), 74-88.

\title{
Kinder-caring: Exploring the Use and Effects of Sociodrama in a Kindergarten Classroom
}

\author{
Dr. Deanna Pecaski McLennan \\ Greater Essex County District School Board, Canada
}

\begin{abstract}
This a/r/tographic inquiry looks at how senior kindergarten students experienced sociodramatic activities based on the work of Moreno (1943) and Boal (1985; $1995 ; 1998 ; 2002 ; 2006$ ). By exploring sociodrama, 11 students (six males and five females) from one senior kindergarten classroom were encouraged to create and reflect upon common social issues as a classroom community through warm ups, sociodramatic activities, and oral group reflections. By the conclusion of the 12th workshop, students were able to participate in the sociodramatic process, including exploring and reflecting on issues of personal and collective importance.
\end{abstract}

\section{Kinder-caring: exploring the use and effects of sociodrama in a kindergarten classroom}

Commencing school is one of the most important milestones in a young child's life. Kindergarten should be an empowering journey that gives students the opportunity to create personal, invested meanings of the world and their place in it. Collaborative exploration with peers is an opportunity to engage in authentic, learning based play activities that promote a sense of excitement and wonder. However, in this age of academic rigour and accountability, facilitating an environment that promotes individual student voice, exploration and choice is often challenging. Teachers often dictate what learning opportunities are available, and knowledge is viewed as an object passed from teacher to student (Friere, 1970; Cook-Sather, 2002; Diaz Soto \& Swadener, 2002; Richard-Amato, 2002; Langen, 2004). Students are often subjected to oppressive 
descriptions of 'best' or 'developmentally appropriate practice' that do not necessarily meet their needs or interests (Diaz Soto \& Swadener, 2002: 40).

When considering how to move away from the 'single best way' bureaucratisation of kindergarten, that focuses on the acquisition of standardised basic skills, in preparation for the production of a 'stable, well-prepared workforce for the future' (Carlson, 1992; Dahlberg et al., 1999: 45) one should consider how the use of sociodrama in classrooms might provide students with an aesthetic outlet for engagement, exploration, and meaning-making. Early years education should be an opportunity for individual and collective artistic inquiry, experience, and reflection (Irwin, 2003; Irwin \& de Cosson, 2004).

\section{Sociodrama}

Sociodrama was first conceptualised by Moreno (1943) following his post World War I therapeutic work with young children. By using dramatic techniques including role play, improvisation and tableau, sociodrama seeks to provide an action oriented, group centred approach to exploring and analysing personal and group social situations. According to Eckloff (2006), sociodrama has three primary goals: enhancing a person's understanding of social situations; increasing understanding of one's or another's roles in social situations and allowing participants to release their emotions by expressing thoughts and feelings about social situations. Engaging people in spontaneous dramatic activities invokes discussion, exploration, and the role playing of solutions to social conflicts or issues of importance (Kellerman, 1998).

There are many varieties of sociodrama, as it has been used extensively as a way for people to examine, resolve, and reflect upon individual and collective social problems, including such diverse issues as poverty, loneliness, racism, sexism, political oppression, and aging (Schutzman \& Cohen-Cruz, 1994; Stein et al.,1995; Lambie et al., 1997; Sime \& Lee, 1998; Grieco \& Chambliss, 2001; Trzinski \& Higgins 2001). The sociodramatic process is as follows. First participants must choose a social problem that is common to most in the group. Actors then improvise and role play the subject. As each issue is portrayed, audience members spontaneously suggest different actions or resolutions in an effort to improve their understanding and influence their future involvement. 'As new insights or breakthroughs occur, these too can be practiced and evaluated' (Torrance, 1975: 185). Rich and Cargile (2004: 352) explained that social drama can occur in the classroom when 'the relative tranquility of norm governed social interaction is upset and attempts are subsequently made to establish new, or reestablish old modes of behavior'. Participants become empowered by collectively exploring and resolving shared problems. 


\section{Theatre of the Oppressed}

Theatre of the Oppressed is a specialised, interactive sociodrama that was devised by Augusto Boal in the 1970s (Boal, 1985; 1995; 1998; 2002; 2006). It encompasses many activities that are similar to Moreno's (1943) sociodrama, including sharing participants' experiences, warm up activities, structured exercises, and individual and group reflection (Paterson \& Weinberg, 1996). Yet it goes beyond by fully engaging the audience, bringing them into the action instead of allowing them to be passive onlookers. These spectators were renamed 'spectactors' as they are just as important as the actors (Boal, 1985). 'In an effort to transform theatre from the monologue of traditional performance into a dialogue between audience and stage' (Paterson \& Weinberg, 1996: 19) spectactors participate actively in the sociodramatic process by suggesting changes to the dramatic activities they are witnessing. Spectactors stop the action to suggest something and see actors give life to their ideas. Participants (actors and spectactors) rehearse strategies for personal and social change through this theatrical exploration (Schutzman $\&$ Cohen-Cruz, 1994).

\section{Research design}

In the tradition of a/r/tography (Felshin, 1995; Eisner, 1998; Piirto, 2002; Cole et al., 2003; Finley, 2005) I undertook this qualitative study to explore whether kindergarten students could 'define themselves not as passive spectators but rather as active participants in artworks' (Finley, 2005: 684) and use sociodrama to explore and reflect on matters of personal and collective importance. I invited 11 students (six males and five females) and their teacher to participate in my study. The research was designed to investigate whether sociodrama could be used in a senior kindergarten classroom and what the effects of sociodrama workshops would be. Themes or issues generated by the drama would be examined. As the non-participant observer I documented the facets of dramatic art that students chose to create. As the expert artist I planned the workshops in collaboration with the teacher. Prior to the workshops I trained and prepared the teacher to lead the students through the dramatic activities. As each workshop unfolded, I observed and documented the students' individual and collective responses using field notes, reflexive journals, oral statements from students, interviews and personal correspondence with the teacher. Student experiences, as I observed and interpreted them, were in the form of narratives in an effort to a/r/tographically represent the lived moments from the workshops and the students' evolving artistic abilities. This 'coming together of art and graphy, or image and word' (Springgay et al., 2005: 900) gave me a layered representation of the students' experiences.

Using modified activities outlined in the sociodramatic work of Moreno (1943) and Boal $(1985 ; 1995 ; 1998 ; 2002 ; 2006)$ including aspects of Theatre of the Oppressed as well as expectations outlined in the Ontario Ministry of Education's (2006) curriculum document for kindergarten, the sociodrama workshops in my study were designed to allow multiple opportunities for students to artistically examine, enact, role 
play and reflect on issues, themes, and ideas of personal and collective importance. Qualitative data were collected to explore the effects and transference of issues and themes generated by the workshops. This $\mathrm{a} / \mathrm{r} / \mathrm{tographic}$ research was an opportunity to equally explore the two domains of theatrical (sociodrama) and educational (kindergarten) research (Piirto, 2002).

\section{The Sociodramatic workshops — creating an aesthetics of kinder- caring}

\section{Warm up}

Each workshop began with a warm up to give students the opportunity to feel comfortable in the environment and with working with each other (Eckloff, 2006). For the purposes of this study, warm ups were based on Boal's (2002) Games for Actors and Non-actors (2nd ed.). Activities from this book helped prepare students to engage in sociodrama by encouraging them to experiment with physical movements and relations between people and objects. Games are of particular importance as they become 'metaphors for social life' (Boal, 2006: 37). Warm ups included muscular, sensory, memory, imagination and emotion exercises in an effort improve awareness and development of each area in preparation for sociodramatic action.

According to Boal (2002: 264), warm ups also act as a 'communion' which helps bind the group into a 'real group, rather than a mere juxtaposition of individuals', perhaps resulting in a safe and trusting space that promotes the sharing of ideas and risk taking. Boal (2002) also emphasised the importance of warm ups as they encourage people to participate in the activities. This was especially important for the students as they were beginning artists, with little dramatic arts experience, at the commencement of my study.

\section{Sociodramatic activity}

Before sociodramatic action begins, students must collectively decide what they wish to explore in the drama. Typically, this is done via group discussion. However, this may be a difficult concept and task for young students, especially those with limited drama experience. According to Eckloff (2006), students that engage in a sociodrama may arrive at its topic by looking at pictures or stories. In this study, four commonly used picture books in kindergarten classrooms: We Share Everything (Munsch, 1999), I Was So Mad (Mayer, 1983), Corduroy (Freeman, 1968) and Bunny Cakes (Wells, 1997) were used as prompts. These books were chosen in consultation with the classroom teacher and explored sharing with others, turn taking, feeling anger and disappointment, loneliness, losing something of importance, being understood, and sibling issues. 


\section{Discussion}

At the conclusion of each workshop all participants engaged in an oral, whole group discussion of the sociodrama. This helped participants verbalise how they felt about the sociodrama and the moments of motivation, purpose, behaviour, possibilities and/or preventions of the events explored in the drama (Eckloff, 2006). According to Boal (2002), sociodramas never really end as the thoughts and actions explored continue to permeate participants' conscious and unconscious thinking and actions. Sociodrama 'encourage[s] autonomous activity, to set a process in motion, to stimulate transformative creativity, to change spectators into protagonists' (Boal, 2002: 275). By concluding each workshop with an oral discussion and reflection, participants had the opportunity to think back on their involvement and imagine how it might extend into their lives.

\section{Sociodrama appears possible with senior kindergarten students}

In order for sociodrama to be successful in an educational setting, students must be engaged in, and respond to, a number of activities (Riley 1990; Eckloff, 2006) including warm ups, the role playing of a common social problem and alternative responses it, and finally a reflection period (Torrance, 1975; Boal, 1985; 2002; 2006; Riley, 1990; Schutzman \& Cohen-Cruz, 1994). By observing the students and their artistic explorations in each of the workshops and analysing the data, it was evident that, by the conclusion of the study, students were able to participate in sociodrama.

At the beginning of the 12 workshops, students were prompted and encouraged by their teacher at every step of their involvement. Ideas about what to explore in the sociodramas came from communal reading of storybooks, and isolating social issues and concerns was accomplished by much closed questioning (for example, the teacher used lots of yes and no comprehension questions to ensure students understood the events, characters and setting of the book). The acting within scenes was mechanical and prescribed by the teacher. Observations from the dramas and reflexive journal entries revealed that the students' first few attempts at sociodrama were awkward and painful to watch (author, 2007) as the actors exploring the initial ideas required step-by-step instructions and encouragement to complete any action or line of dialogue. The teacher had to direct each student in everything they said and did. This confusion, disorganisation and lack of dramatic experience hindered the spontaneity of the sociodramas and prevented students from claiming the scenes as their own. With the teacher selecting books and topics and leading group discussions, selecting actors and directing every element of the sociodramas, one could hardly claim that the students' experiences in the first few workshops truly reflected what they were concerned about.

This routine continued through workshops three, four and five, where students who volunteered to act would begin each scene by starring blankly at their teacher and the spectators on the carpet until the teacher would relieve them by reminding them of the issues explored in the storybook and suggesting actions and words for each student. 
Some students were unable to speak as their character even with prompting and encouragement from the teacher. Others asked for the scene's main ideas to be repeated a number of times before attempting to act in character. Some students were able to move as their characters but unable to maintain a dialogue with each other in role. This constant interrupting of the scene by the students asking for assistance, as well as the teacher providing step-by-step instructions for movement and dialogue, were both frustrating for everyone involved in the workshops and did not reflect the spontaneous nature of sociodrama (author, 2007). With each interruption, some students would groan and sigh as they waited for the drama to continue.

Although the teacher still prompted and encouraged from the audience, many students no longer required step-by-step directions in workshop six and later. Students were beginning to suggest the first scene the class should explore, rather than referring to a picture book. Other students worked with their peers, prompting them from within the scene instead of relying on the teacher. Students began to experiment with improvisation, replacing each other in scenes in order to present an alternative action or resolution to the conflict being explored-something that until this point they were unable to do. This was a pivotal moment. Students began to function as both actors and explorers, acting in character but also stepping out to prompt a fellow actor, or to suggest alternative actions. The transformation of students' ability to dramatise a character, improvise and work to find alternative responses to the conflicts was amazing.

Towards the conclusion of the workshops, students suggested situations to explore-important situations that were occurring in their lives and were of concern to them. As indicated by one student in discussion with her teacher in workshop 12: 'That problem happened yesterday and I keep thinking about it'. Students also suggested ways to extend the exploration into the rest of the daily schedule. In workshop nine, students asked that the book Corduroy (Freeman, 1968) and the stuffed Corduroy bear be placed in the reading centre so students could continue to explore them and role play during their activity time. At the conclusion of workshops seven, eight and nine, students created a bulletin board display in the hallway outside their classroom to showcase their dramatic work and responses to the Corduroy book. Through personal artwork they portrayed how they felt and responded when they lost something of importance. My reflexive journal entries revealed that by the final few workshops, students appeared to have become risk takers and problem solvers within and outside the workshops. They were beginning to own their sociodramatic experiences (author, 2007).

Following an examination of multiple sociodramatic experiences and moments from the drama, it was apparent that the senior kindergarten students were able to interact successfully within the sociodrama activities and had developed as actors by the end of my study. By the 12th workshop, students appeared able to discuss matters of importance to them in the group format, to improvise role playing a selected scene, and to brainstorm and role play alternative responses or solutions to the problem. Students demonstrated these abilities repeatedly and began to extend their interactions into their 
playtime outside the sociodramatic workshops. Although students involved themselves in the different components of the workshops (for example, warm ups, discussions, sociodramas) in varied ways, each was involved in their own unique way. According to Taussig and Schechner (1994: 28-9)

All the participants in a forum workshop learn something, become more aware of some problems that they did not consider before, because a standard model is challenged and the idea that there are alternatives is clearly demonstrated. We never try to find which solution proposed is the 'correct' one.

\section{Difficulties implementing sociodrama with young children}

From the above discussion one can see that although sociodrama is meant to be collectively created, experienced and reflected on by the participants, this was normally not the case with the senior kindergarten class. The workshops were mainly directed by the teacher, especially in the first half of my study. Although workshops were designed so that the social issues presented in each picture book would lead students to explore personal issues (for example, the book was presented, the issues in the book were explored, and then students were encouraged to think of problems or concerns that they could share with the group), quite often students chose to focus on the issues presented in the picture books even when their teacher prompted them to contribute their own experiences and concerns. Perhaps students were not yet comfortable enough with the drama activities to freely explore their own ideas, as they had had little experience with drama in the classroom prior to this workshop. Drama skills are an asset for participants who explore sociodrama, including an understanding of what a character is, how to improvise dialogue, how to utilise the body (for example, gestures, facial expressions, levelling and positioning the body) and how to portray emotions using tone of voice and body language. If students did not understand or feel comfortable with these drama tools, it appears reasonable to assume that at the beginning of the study sociodrama would be more teacher directed as students became familiar with and practised these basic dramatic elements.

In addition to requiring some background experience in dramatic arts, students that participate in sociodramatic activities also need some sort of common theme, element or problem to fully participate in a true sociodramatic process. As it was originally designed for use with government oppressed people in Brazil, participants in the original Theatre of the Oppressed sociodrama (Boal, 1985; 2002) may have been a fairly homogenous group, the majority of who had some difficulty in common. Instead, students in this study came from a very diverse ethnic and cultural background. Is it harder for people from different backgrounds to find common interests or concerns to collectively explore than a homogeneous group of people? This diversity may have also affected the students' ability to move beyond the teacher directed, picture book inspired issues in the sociodrama. 


\section{Classroom structure}

Although student involvement in and commitment to the sociodrama appeared to increase with each workshop, many extrinsic influences may have affected the way students experienced the activities. The physical environment of the classroom, expectations of student behaviour and participation, and outside interruptions all may have influenced the way students interacted.

Before students can fully engage with the educational process, including participation in the arts, the most basic of their needs must be met (Maslow, 1968). Students must feel safe in the classroom before advanced learning and engagement can take place. This safe space is also essential for active and meaningful participation in drama (Way, 1967; Warren, 1993, author \& Smith, 2007). Participants should feel that they are able to take risks in their personal exploration and that they are free from personal shame, embarrassment or vulnerability. During each workshop every effort was made to ensure that the classroom environment was both supportive and physically and psychologically safe for the students. Taylor (1994) suggested that students need to feel comfortable in their immediate environment in order to participate successfully in drama. Way (1967) defined a safe drama space as a physically inviting and warm environment large enough to allow students free movement. This 'infinite space' (Boal, 2002: 162) that is full of possibility should be isolated from the rest of the school, so that outsiders cannot influence the drama or make the performers anxious. This safe environment makes the students comfortable and trusting so that they can freely explore issues, feelings, and unfamiliar situations (Way, 1967; Blum, 1999; author \& Smith, 2007).

In addition to a safe and supportive physical environment, students who are experiencing the full possibilities of sociodrama need to engage with each other and interact within a psychologically supportive environment. In this space each student's ideas are valued and the sociodrama facilitator is willing and able to implement all suggestions, allowing the direction of the activities to ebb and flow with the needs and desires of the participants. The context within which the sociodrama is played out has a critical role in facilitating and constraining the sociodrama.

\section{Crowded environment}

Although the senior kindergarten classroom was warm and bright, it was rather small, overflowing with shelves, tables and chairs, and bins of learning materials. Colourful posters, artwork and schedules were displayed on every wall. Students participated in the workshops on the large communal carpet adjacent to the wall as there was no other open space in the classroom large enough to permit small groups of students the room they needed for open and large movements. During warm up activities that required students to move around the room, movement was limited to walking around tables and chairs and often students would bump into one another or need to pause and wait for another student to move out of the way. During sociodrama scenes spectactors remained seated 
on the carpet and the actors would stand in front of them, cramped in the space between the carpet and the tables and chairs. This small space may have hindered some movements that students might have made had they more room. The classroom was used as it was important for students to experience the new sociodramatic activities in a safe and familiar space, without outside influences affecting their comfort or involvement. Perhaps staging the workshops in a larger space such as the school library or gym might have encouraged different movements or levels of participation in some of the more active warm ups and sociodrama scenes.

\section{Established classroom rules and routines}

de Cosson et al. (2003) metaphorically described the rigid, invisible expectations in elementary schools that limit the range of student expression and experience in the arts. A bulletin board, meant to display student created artwork, showcases the hidden power structures in the classroom and how even in activities such as visual art, where students can create unique pieces of art, the underlying expectations and rules of the teacher can hinder free expression and spontaneity.

The space right outside the classroom in essence belongs to the teacher inside. Every bulletin board is unique yet similar. The latest art show, writing exercise, class project, oh so carefully displayed for fellow teachers to compliment us on our fine and sometimes Herculean efforts at presentation. We arrange according to our own aesthetic. We hope our colleagues recognize our great work. We expect the complimentary staff room comments. 'Oh what a great project you got your kids to do; it looks wonderful!' Everything straight, arranged to an exact grid, very seldom is the colouring allowed outside the lines. Do we ever consider our children's aesthetics as we paste and staple those masterpieces? Do we realize how conforming this structure is and how defined the silent expectations are? (de Cosson et al., 2003: 11-2)

Like the bulletin board's structure that silently oppresses students' aesthetic experience, the physical environment of this study with its established classroom rules and procedures may have also influenced student spontaneity and engagement. In this classroom, students were expected to raise their hand and be called upon by the teacher before speaking, to sit cross legged on the carpet when attending to another, not to call out ideas spontaneously, to take turns with one another, and to always attend to whatever was happening at the particular teaching moment. Often the teacher would halt the sociodrama when a student was not following the established classroom rules, call the student's name and wait for his or her attention, and in extreme circumstances, ask a student to remove him or herself from the carpet and sit on a chair. These behaviour modifications and redirections were observed in every workshop and addressed, in particular, behaviour demonstrated by the same students over and over again. Often the teacher's verbal redirection would interrupt an activity, causing the students who were participating to stop and wait for the redirection before resuming their activity.

Although the teacher encouraged students to take risks and be creative, the highly structured rules of the classroom (for example, raising hands before answering questions, 
speaking one at a time, sitting in a circle) may have discouraged spontaneity. As a result, the sociodramatic process, which encourages a continuous stream of dialogue between actors portraying a scene, and spectators critiquing and suggesting changes may have been repressed. One of the key elements of successful sociodrama is a participant's ability to engage spontaneously with the drama (Zachariah \& Moreno, 2006). Students who are required to raise their hand before suggesting an idea or replacing an actor in a sociodrama scene may not have their idea accepted as quickly or may be repressed by the process.

\section{The value of sociodrama in the senior kindergarten classroom}

Despite a number of outside influences and disruptions, most students were able to participate actively as actors and spectactors in the warm ups and activities. The main goal of the sociodrama was for students to work together to find alternative responses or resolutions to the situations being explored. Although students initially needed storybooks to help them suggest social issues to engage with, they were consistently able to brainstorm multiple solutions or alternative actions for the problems they encountered. This was evident in every sociodramatic activity.

Although the students' ability to succeed within the technical structure of the sociodramatic artwork (for example, positioning, levels, gestures and body movement) is of some interest, especially considering their lack of knowledge and experience of dramatic art, what is more important is the discovery and connection students appeared to experience beginning in the sixth and continuing until the concluding workshop. Students became more fluid in their dialogue and actions. They worked together to create more complex characters and explorations of the issues. Student responses to conflicts became more complex as they worked together to create more informed, intricate responses to their problems. Unlike oral or written problem solving and discussion (for example, reading a book about a problem and then discussing it, watching a film about successful problem solving) it is this transformative experience of living within the sociodrama, and not just focusing on the technical aspects of the craft, that appeared to be most transformative for students (Wilson, 2004). When students inquired within the connected roles, relationships and issues of sociodramatic activities they were able to freely explore, risk take, retry, reinvent, discover, and solve their social concerns. Learning becomes three dimensional and classroom activity becomes spontaneous, collaborative, and totally student centred.

In the current age of 'dualisms that continue to dominate Western thought [that] are inadequate for understanding a world of multiple causes and effects interacting in complex and nonlinear ways' (Lather, 1991: 21) as expressed through a finite curriculum, rigid classroom structures, and standardised tests, it is easy to see how the inclusion of sociodramatic activities in a kindergarten classroom might begin to provide students with liberating, creative, authentic, and collaborative experiences. Sociodrama, as arts based action and reflection, gives kindergarten students an alternative agent for 
learning and change within the classroom. Classrooms that nurture and celebrate individuality through personal and collective artistic inquiry, experience and reflection encourage all students to become artists-exploring together, asking questions of one another, finding answers and even more questions, reflecting, and teaching one another through arts- and play-based, authentic experiences. This is the true essence of what kindergarten, one of the most important and meaningful structured school experiences that a child will ever have, is really all about.

\section{References}

Amatruda MJ, 2006, 'Conflict resolution and social skill development with children'. Journal of Group Psychotherapy, Psychodrama \& Sociometry, 58(4), 168-81.

Author, 2007.

Author \& Smith K, 2007.

Blum L, 1999, 'Ethnicity, identity, and community'. In Katz M, Noddings N \& Strike K (eds), Justice and caring: The search for common ground in education. Teachers College Press, New York.

Boal A, 1985, Theatre of the oppressed. Theatre Communications Group, New York.

Boal A, 1995, The rainbow of desire: The Boal method of theatre and therapy, Jackson A (trans.). Routledge, London \& New York.

Boal A, 1998, Legislative theatre: Using performance to make politics, Jackson A (trans.). Routledge, London \& New York.

Boal A, 2002, Games for actors and non-actors (2nd ed.), Jackson A (trans.). Routledge, London \& New York.

Boal A, 2006, The aesthetics of the oppressed, Jackson A (trans.). Routledge, Milton Park, Oxon.

Carlson D, 1992, Teachers and crisis: Urban school reform and teachers' work culture. Routledge, New York.

Cole AL, Neilsen L, Knowles JG \& Luciani T, 2003, Provoked by art; Theorizing artsinformed research. Backalong Books \& Centre for Arts-informed Research, Halifax, Nova Scotia \& Toronto, ON.

Cook-Sather A, 2002, 'Authorizing students' perspectives: Toward trust, dialogue, and change in education'. Educational Researcher, 31(4), 3-14. 
Creekmore N \& Madan A, 1981, 'The use of sociodrama as a therapeutic technique with behavior disordered children'. Behavioral Disorders, 7(1), 28-33.

Dahlberg G, Moss P \& Pence A, 1999, Beyond quality in early childhood education and care: Postmodern perspectives. Falmer, London.

de Cosson A, Irwin R, Grauer K \& Wilson S, 2003, 'Hanging identities: Artist's dancing interruptions into corridors of learning'. Paper/performance presented at the International Conference of Imagination and Education, Vancouver, BC.

Diaz Soto L \& Swadener B, 2002, 'Toward liberatory early childhood theory, research and praxis: Decolonizing a field'. Contemporary Issues in Early Childhood, 3(1), $38-66$.

Eckloff M, 2006, 'Using sociodrama to improve communication and understanding'. Etcetera, 63(3), 259-69.

Eisner EW, 1998, The enlightened eye: Qualitative inquiry and the enhancement of educational practice. Prentice Hall, Upper Saddle River, NJ.

Felshin N (ed.), 1995, But is it art? The spirit of art as activism. Bay Press, Seattle, WA.

Finley S, 2005, 'Arts-based inquiry: Performing revolutionary pedagogy'. In Denzin NK \& Lincoln YS (eds), Handbook of Qualitative Research (3rd ed.). Sage, Thousand Oaks, CA.

Freeman D, 1968, Corduroy. Penguin Books USA Ltd, New York.

Freire P, 1970, Pedagogy of the oppressed, Bergman Ramos M (trans.). Herder and Herder, New York.

Grieco M \& Chambliss C, 2001, Educational methods for addressing diversity issues: The use of sociodramatic techniques. ERIC Document Reproduction Service N. ED456368. Ursinus College, Pennsylvania.

Irwin RL, 2003, 'Toward an aesthetic of unfolding in/sights through curriculum'. Journal of the Canadian Association for Curriculum Studies, 1(2), 63-78.

Irwin RL \& de Cosson A (eds.), 2004, A/r/tography: Rendering self through arts-based living inquiry. Pacific Educational Press, Vancouver, British Columbia.

Kellermann PF, 1998, 'Sociodrama'. Group Analysis, 31, 179-95. 
Lambie I, Robson M \& Simmonds L, 1997, 'Embedding psychodrama in a wilderness group program for adolescent sex offenders'. Journal of Offender Rehabilitation, 26(1-2), 89-107.

Landy, R \& Borisoff, D 1987, 'Reach for speech: Communication skills through sociodrama'. English Journal, 76(5), 68-71.

Langen R, 2004, 'Supervising the dance: One hundred years of failed education reform. Have we missed the child'. Education Forum, 30(3), 22-5.

Lather P, 1991, Getting smart: Feminist research and pedagogy with/in the postmodern. Routledge, London.

Maslow J, 1968, Toward a psychology of being. Van Nostrand, New York.

Mayer M, 1983, I was so mad. A Golden Book Publishing Co, Racine, WI.

Moreno JL, 1943, 'The concept of sociodrama: A new approach to the problem of intercultural relations'. Sociometry, 6, 434-49.

Moreno JL, 1953, Who shall survive? (revised edition). Beacon House, Beacon, NY.

Munsch R, 1999, We share everything! Scholastic Inc, Markham, ON.

Noddings N, 1999, 'Care, justice and equity'. In Katz M, Noddings N \& Strike K (eds), Justice and caring: The search for common ground in education. Teachers College Press, New York.

Ontario Ministry of Education, 2006, The kindergarten program (revised). Queen's Printer for Ontario, Toronto.

Paterson DL \& Weinberg M, 1996, 'We are all theatre: An interview with Augusto Boal'. High Performance, Summer, 18-23.

Piirto J, 2002, 'The question of quality and qualifications: Writing inferior poems as qualitative research'. International Journal of Qualitative Studies in Education, 15(4), 431-45.

Pinar WG, 2004, 'Foreword'. In Irwin RL \& de Cosson A (eds), A/r/tography: Rendering self through arts-based living inquiry. Pacific Educational Press, Vancouver, British Columbia. 
Rich MD \& Cargile AC, 2004, 'Beyond the breach: Transforming white identities in the classroom'. Race Ethnicity and Education, 7(4), 351-65.

Richard-Amato P, 2002, 'Sharing power in the classroom'. ESL Magazine, January/February, 16-8.

Riley J, 1990, 'Sociodrama: Group creative problem-solving in action'. Journal of Creative Teaching, January/February, 28-30.

Rosenthal G \& Tetel-Hanks J, 1981, 'A program for intervention in schools'. Education Unlimited, 3(4), 9-16.

Schutzman M \& Cohen-Cruz J (eds), 1994, Playing Boal: Theatre, therapy, activism. Routledge, London.

Sime HS \& Lee JH, 1998, 'A comparative analysis on the therapeutic factors of the psychodrama and sociodrama for juvenile delinquents'. Korean Journal of Counseling \& Psychotherapy, 10(1), 251-71.

Springgay S, Irwin R \& Wilson Kind, 2005, 'A/r/tography as living inquiry through art and text'. Qualitative Inquiry, 11(6), 897-912.

Stein S, Ingersoll R \& Treadwell T, 1995, 'Sociodrama and professional/ethical conflicts'. Journal of Group Psychotherapy, Psychodrama \& Sociometry, 48(1), $31-41$.

Taylor PM, 1994, 'Our "adventure of experiencing": Reflective practice and drama Research'. Youth Theatre Journal, 9, 31-52.

Torrance EP, 1975, 'Sociodrama as a creative problem-solving approach to studying the Future'. Journal of Creative Behavior, 9, 182-95.

Trzinski A \& Higgins J, 2001, 'Therapeutic play activities: Building cohesion and socialization among nursing home residents'. Activities, Adaptation \& Aging, 25(3-4), 121-53.

Warren B, 1993, Using the creative arts in therapy. Routledge, London.

Way B, 1967, Development through drama. Humanities Press, New Jersey.

Wells R, 1997, Bunny Cakes. Puffin Books, New York. 
Wilson S. 2004, 'Fragments: Life writing in image and text'. In Irwin RL \& de Cosson A (eds), A/r/tography: Rendering self through arts-based living inquiry. Pacific Educational Press, Vancouver, British Columbia.

Zachariah M \& Moreno R, 2006, 'Finding my place: The use of sociometric choice and sociodrama for building community in the school classroom'. Journal of Group Psychotherapy, Psychodrama \& Sociometry, 58(4), 157-67. 